\title{
Why do public monuments play such an important role in memory wars?
}

\author{
Connor Deegan
}

In this paper I explore the role played by public monuments in the narration of national stories. I examine several monuments that have been built to promote various national narratives, with a particular focus on the South Australian National War Memorial, located in Adelaide, Australia. My analysis reveals that monuments have a dynamic capacity to embody simplified narratives of the past, and to shape collective memory accordingly. I contend that, owing to this capacity, monuments play a significant role in the narration of national stories. I also consider the power of monuments to serve vehicles for the promulgation of dissenting narrative strands. I ultimately argue that the prevalence of such strands reveals that many "memory wars" can never definitively be won - that is, that it is impossible to achieve homogeneity in history. 


\section{Introduction}

Monuments fill public spaces across the world. They are intended to set in stone the people and events that have shaped a society's shared history. However, what is recorded as "history" is not the same as "the past." It is only the past that is truly set in stone. History, on the other hand, is constantly created; it can be defined as "the reconstruction, always problematic and incomplete, of what is no longer." The events of time gone by, like anything else that "is no longer," may be reconstructed to take any number of forms. The question of exactly how the past should be remembered is the source of conflicts the world over. Such conflicts are often underpinned by nationalist sentiments, and can be described as "memory wars." Public monuments are frequently deployed as weapons in the fighting of these wars. In this paper I will examine several monuments that have been built to promote various national narratives. I will argue that the importance of monuments in memory wars owes largely to their unique power to shape collective memory. My analysis will also reveal that monuments serve as vehicles through which the very narrative of the past that they were built to reinforce can be contested, revealing the impossibility of achieving homogeneity in history.

\section{Collective memory, the "mythscape," and nationalism}

To properly appreciate the importance of monuments in the fighting of memory wars, it is necessary to understand the concepts of collective memory, the mythscape, and nationalism. The notion of collective memory was first postulated by French theorist Maurice Halbwachs. ${ }^{2}$ Halbwachs asserts that it is in society that we acquire most of our memories. He argues that there exists a collective memory, and that "it is to the degree that our individual thought... participates in this memory that it is capable of the act of recollection." The power that follows from acquiring control of a group's collective memory thus becomes apparent. This power is the prize over which many memory wars are fought, and it is on the mythscape that the fascinating battles of these wars play out.

The mythscape is a conceptual space first theorised by Duncan Bell. ${ }^{4}$ Bell states that the mythscape is the "discursive realm wherein the struggle for control of people's memories and the formation of nationalist myths is debated, contested and subverted incessantly." Although Bell does not elaborate as to exactly what comprises the mythscape, it is clear that public monuments are one important aspect of it. It is significant that Bell refers explicitly to nationalist myths in his definition of the mythscape. Indeed, it is the desire to promote nationalism that often motivates attempts to shape collective memory.

\footnotetext{
1 Pierre Nora, "Between memory and history: Les lieux de mémoire" Representations, 26 (1989), 8.

${ }^{2}$ Maurice Halbwachs, On Collective Memory (Chicago: University of Chicago Press, 1992).

3 Ibid, 38.

${ }^{4}$ Duncan Bell, "Mythscapes: Memory, Mythology and National Identity" British Journal of Sociology, 54:1 (2003).

5 Ibid, 66.
} 
Peter Alter, in his 1994 book Nationalism, defines nationalism as "an ideology... which holds the nation and sovereign nation-state to be crucial indwelling values, and which manages to mobilise the political will of a people. ${ }^{6,}$ By definition, nationalism relies on the purported existence of a nation. It is noteworthy that in defining nationalism, Alter refers to the "nation" as distinct from the "sovereign nation-state." What, then, defines a nation, if not its status as a political entity? The answer is different in the case of every nation worldwide, many of which are not sovereign nation-states at all. For some, it is ethnicity. For others, language. Above all, at the core of every nation is a narrative that seeks to give meaning to past events and to collectivise the memory of a people. Homi Bhabha argues that a narrative is all that a nation truly is. ${ }^{7}$ In formulating a coherent narrative linking the past with the present and future, the power of present rulers can be legitimised, national ideology galvanised, and political will mobilised.

\section{The dynamicity of monuments: overt and banal shaping of memory}

The mythscape is composed of many things: school textbooks, film, and song, to name a few. The importance of monuments as a component of the mythscape owes partly to their dynamic capacity to shape collective memory. The shaping of collective memory can be divided into two distinct conceptual categories: overt shaping of memory and banal shaping of memory. Monuments are capable of contributing to both. A typical example of overt shaping of collective memory is the creation of national days of remembrance. This is overt in that it stands out from the banality of regular routine. With respect to national narratives, it is through the overt shaping of memory that important figures and events, both the heroic and the villainous, the celebrated and the grieved, are identified and explained. The role played by monuments in this process is often significant.

This is conveniently demonstrated by an analysis of a monument located in the city that I call home: the South Australian National War Memorial, situated in the central business district of Adelaide. Built during the 1930s, the memorial commemorates the loss of Australian lives in World War One. The memorial depicts the 'Angel of Duty' on one side and the 'Angel of Compassion' on the other, and 'represents... calling young people to war and sacrifice." It embodies two important aspects of the national narrative that has ostensibly prevailed in Australia over the past 100 or so years. Firstly, Angels are synonymous with Christianity, and by adorning the National War Memorial with such symbols, the government reinforces that Christianity is part of Australia's national identity. Secondly, the monument promotes the notion that Australians have suffered for the good of the nation, or that the nation itself, which is personified in the monument, has suffered. It is on this notion that the typical Australian narrative has come to focus most pointedly, with ANZAC Day being the most "sacred" day in Australia's memory culture."

\footnotetext{
6 Peter Alter, Nationalism (London: E. Arnold, 1994), 4.

${ }^{7}$ Homi K. Bhabha, Nation and Narration (London; New York: Routledge, 1990).

8 Plaque at South Australian National War Memorial, North Terrace, Adelaide, Australia.

${ }^{9}$ Carolyn Holbrook, "How ANZAC Day came to occupy a sacred place in Australians' hearts", SBS, 25 April 2017.
} 
A nearby plaque bears an image captured at the memorial's unveiling, which was attended by 75,000 people. Clearly, such an occasion breaks with the banality of regular routine. With the memorial at the centre of their attention, these people would have consciously engaged with the narrative of the past that the memorial seeks to promote. This is a classic example of the overt shaping of a people's collective memory.

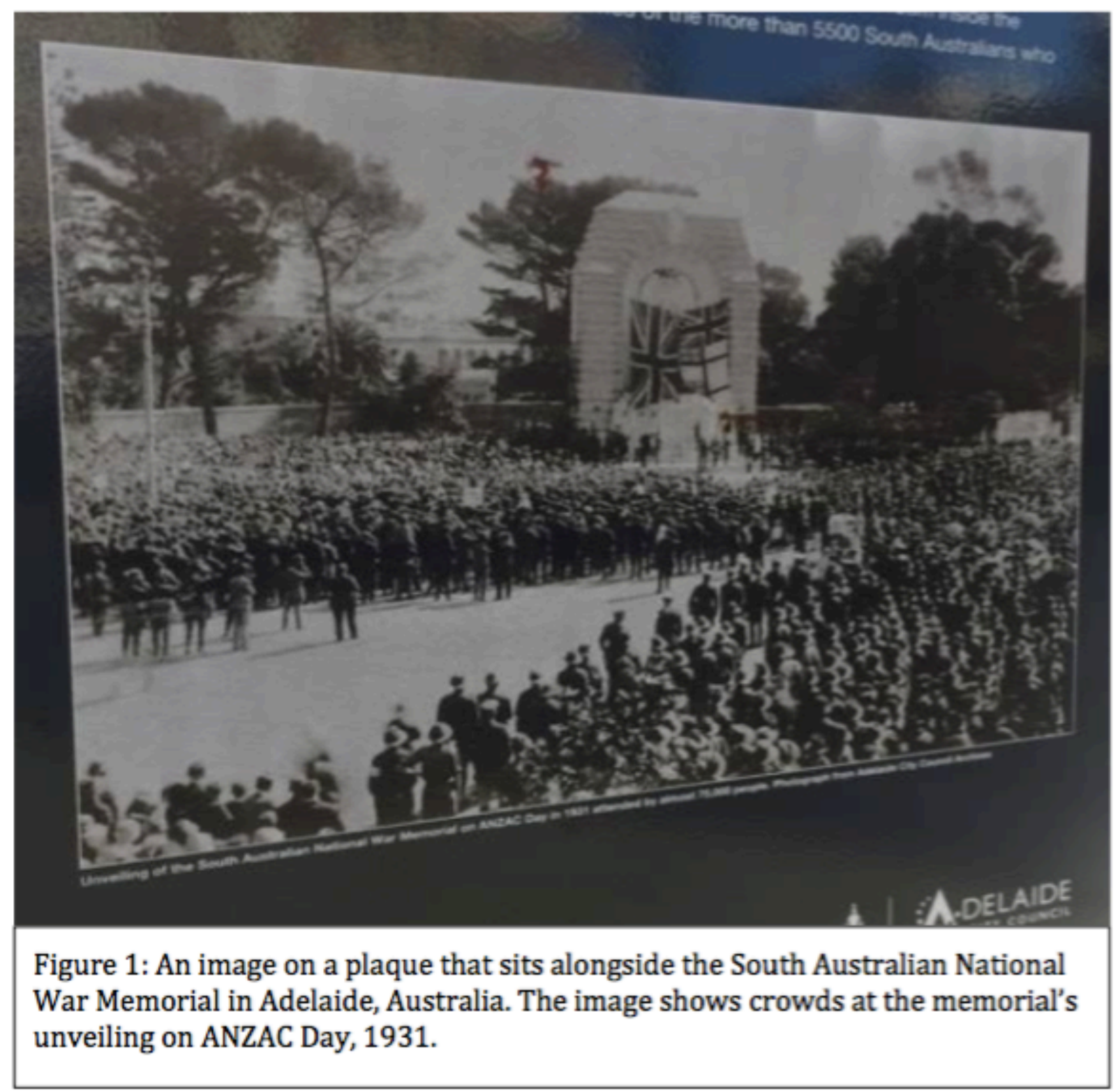

In permeating public space, monuments also shape memory in a more banal way. I have borrowed the concept of banal shaping of collective memory from Michael Billig (1995), by adapting what he termed "banal nationalism. ${ }^{10}$ " While Billig focused on displays of nationalism generally, I will focus only on those that seek to shape collective memory. To explain banal nationalism, Billig drew a distinction between the flag that is "waved" at, say, a sporting event, and the "unwaved" flag that hangs from a public building. " Billig asserts that, despite being "so forgettable", the

10 Michael Billig, Banal Nationalism (London: Thousand Oaks, 1995).

11 Billig, Banal Nationalism, 10. 
unwaved flag is at least as important as the waved flag in reinforcing national identity. ${ }^{12}$ I contend that it is through banal references to past events that collective memory is reinforced on a day-to-day basis. To explain the power of monuments as a tool in the banal shaping of collective memory, I will return again to discuss the South Australian National War Memorial.

The memorial is situated in one of the busiest public areas of Adelaide, and is passed by thousands of pedestrians each day. I surveyed some of these pedestrians in June 2017. I acknowledge that my sample size is far less than ideal, and that this must be kept in mind when drawing conclusions from my results. Despite this, I believe that the responses, shown below, offer a cogent summary of the manner in which the memorial contributes to the banal shaping of the collective memory of Adelaide's civilians.

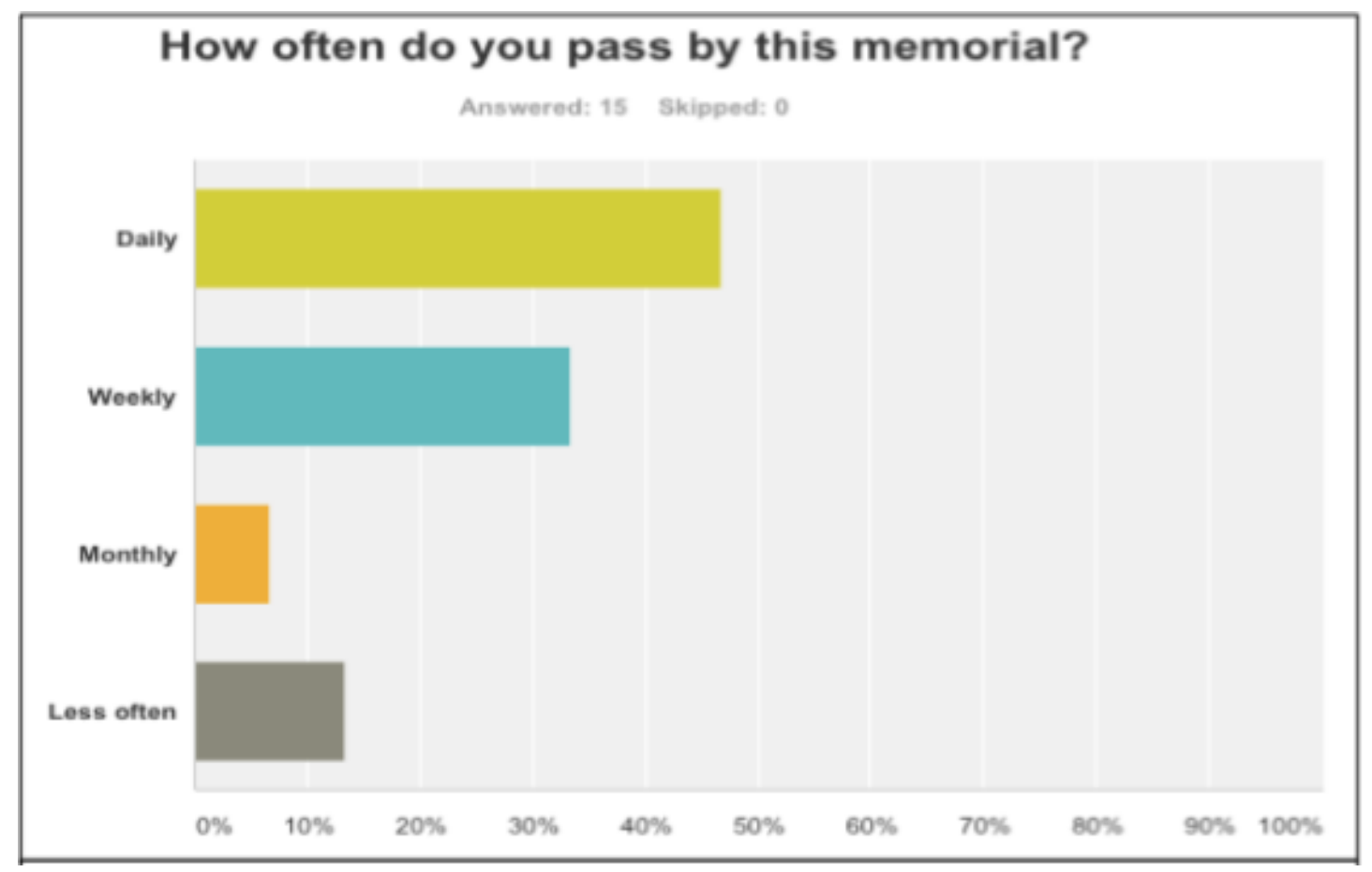

12 Ibid. 


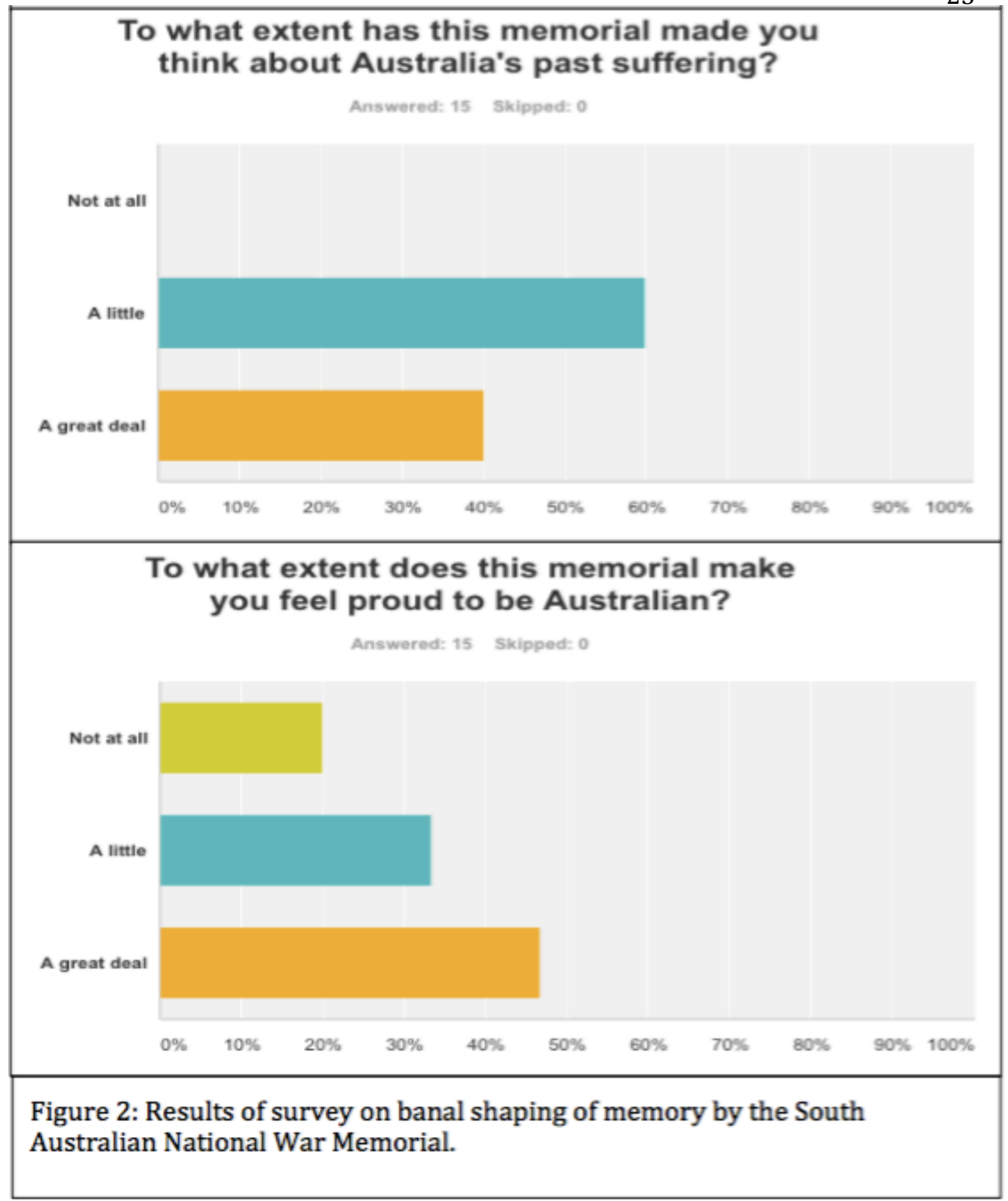

In order to participate in the survey, prospective respondents had to confirm that they considered themselves to be "Australian", and that they understood what the memorial commemorates. I acknowledge that this second question is somewhat leading in that is draws respondents' attention specifically to Australia's suffering. This could have caused some respondents to overstate the extent to which the monument has actually caused them to think about that suffering. However, the results are still significant; all respondents indicated that the memorial has led them to think about Australia's past suffering at least "a little," and for $40 \%$ of respondents, "a great deal." Given that the majority of respondents pass by the monument at least weekly, it is clear that the memorial reinforces Australia's past suffering routinely. 
With comparable monuments located in cities across the globe, ${ }^{13}$ this is likely reflective of a broad trend in the shaping of collective memory throughout the contemporary world. ${ }^{14}$

\section{Setting-in-stone simplified narratives: victimhood and heroism}

The dynamicity of monuments in shaping collective memory is complemented by the simplicity with which they do so. National narratives tend to simplify past events and personalities around which collective memory can be shaped, and around which the overall narrative can be based. As I have mentioned, one particularly prevalent tendency of national narratives is to identify the nation as having endured past sufferings. Numerous narratives go further than simply focusing on suffering; in many cases, national identity is predicated on utter victimhood. Victimhood is a particularly powerful narrative trope, as it can serve to legitimise a nation's very existence. ${ }^{15}$

To take but one example, victimhood is particularly important to the national narrative currently propagated by the government of Ukraine, and arguably serves as the very basis upon which modern Ukraine is founded. Historian David Marples has argued that the narrative promoted by the Ukrainian government is essentially a statement to the effect of: "Because of our past suffering under a Moscow-based regime, we are now entitled to an independent state. ${ }^{16}$ "Ukraine's victimhood at the hands of Russia is most famously captured by the story of the Holodomor. The Holodomor was a famine that occurred during the 1930s, when Ukraine was part of the Soviet Union. The Ukrainian government memorialises this event in monuments around the country, including in the "Bitter Memory of Childhood" memorial, situated in Kiev. This memorial takes the form of a "haunting" statute of a clearly malnourished girl, clutching a handful of wheat. ${ }^{17}$ The girl is intended to embody the personality of the Ukrainian nation as a whole. Such an image represents vulnerability, innocence, even gentleness. It commands empathy, and leaves no room to contest Ukraine's status as a victim.

This focus on oppression at the hands of Russia also fuels the legend of the man who many Ukrainians have come to identify as their national hero: Stepan Bandera.

Despite the fact that Bandera collaborated with German Nazis, the Ukrainian government has erected numerous monuments to promote his supposed heroism. ${ }^{18} \mathrm{It}$ is in the statue of the hero that monuments are at their most powerfully concise in their narration of national stories. It goes without saying that a person commemorated by a statue is to be venerated, and that their deeds are to be celebrated. Indeed, the

\footnotetext{
13 No specified author, "Leicester and New Delhi war memorials link ceremonies", BBC, 25 May 2017.

${ }^{14}$ Kevin Basi, "What we can learn from war memorials", Allied News, 4 June 2017.

15 David Marples, Heroes and Villains: Creating National History in Contemporary Ukraine

(Budapest: Central European University Press, 2007), x.

16 Ibid.

17 Will Chabun, "Poignant commemoration of Holodomor tragedy in Regina”, Regina Leader Post, 21 November 2016.

18 Andrii Portnov, "Bandera mythologies and their traps for Ukraine", Open Democracy, 22 June 2016.
} 
phrase "put on a pedestal," now synonymous with such words as sanctify and idolise, is born of a metaphorical reference to the statue.

In all cases, whether they are conveying victimhood or heroism, monuments embrace the simplicity of national narratives. Other aspects of the mythscape, such as a historian's essay, or even a politician's speech, cannot necessarily disregard questions of context with such ease. Monuments necessarily whittle history down to simplified versions of events and personalities. They naturally embody the facile narratives propagated by those who seek to shape collective memory: easily digestible, but, as evidenced by Ukraine's incessant portrayal of Stepan Bandera as a hero, not necessarily reflective of the past.

\section{Interaction with other aspects of the mythscape}

This simplicity makes monuments a valuable foil for other aspects of the mythscape. For example, monuments are frequently utilised to lend efficacy to school history curriculums. In Azerbaijan, the government has developed a comprehensive program aimed at instilling in school children a sense that Azerbaijan has long been a victim of Armenian aggression. ${ }^{19}$ As part of this program, Azerbaijani students are forced to visit memorials that reinforce this basic narrative. ${ }^{20}$ The Australian government makes similar use of monuments. During the two hours that I stood on North Terrace gathering responses for my survey, three classes of school children examined the memorial and the surrounding plaques. Monuments also regularly serve as bases for commemorative events, ${ }^{21}$ diplomatic ceremonies, ${ }^{22}$ and the delivering of politicians' speeches. $^{23}$

\section{Facilitating the expression of dissent}

Ironically, monuments are also mediums through which the very narratives that they have been built to promote can be challenged. Indeed, it is often through vandalism that monuments are brought to our attention. A recent example is found in New Zealand. There, two statues of Captain James Cook, the first British man to sail to the Pacific nation, were defaced in $2016 .{ }^{24}$ Clearly, in constructing these statues, the New Zealand government has identified Cook as someone who is to be venerated. However, some New Zealanders promote a narrative of their nation's past in which Cook is not a hero, but a villain. This is because Cook allegedly shot several Maori people upon landing at the New Zealand's Bay of Poverty in $1769 .{ }^{25}$ Drawing

\footnotetext{
${ }^{19}$ Akhundov, Sabir, "Azerbaijanism", Open Democracy, 3 August 2016.

${ }^{20}$ No specified author, "Our students visited Guba genocide cemetery", Azerbaijan Republic Gabana Region Executive Power News, 19 November 2015.

${ }^{21}$ Hannah Blacklston, "Where and how to commemorate ANZAC Day in your capital city", Nine.com.au, 22 April 2017.

${ }^{22}$ No specified author, "Queen lays wreath at Tomb of Unknown Soldier in Paris", BBC, 5 June 2014.

${ }^{23}$ Brooke Singman, "President Trump Gives Memorial Day Address at Arlington National Cemetery", Fox News, 29 May, 2017.

${ }^{24}$ Eleanor Roy, "Captain Cook statues defaced in NZ amid calls for Maori chiefs to take his place", The Guardian, 31 July 2016.

${ }^{25}$ Roy, "Captain Cook statues defaced in NZ amid calls for Maori chiefs to take his place".
} 
attention to this alternative version of the national narrative was presumably the goal of the vandals. Given the media coverage that the incident received, and the ensuing discussion of Cook's misdeeds, this goal was realised with great success. ${ }^{26}$ The importance of monuments to the expression of dissent is augmented by the fact that less radical means of challenging national narratives, such as publishing academic papers, or lobbying members of Parliament, do not generally receive media attention. In fact, in many countries, these avenues of dissent are not even available; in Ukraine, it is now illegal to "publicly exhibit a disrespectful attitude" towards Stepan Bandera. $^{27}$

\section{What does this reveal about national narratives and collective memory?}

The vandalism of monuments, a phenomenon that occurs across the world, ${ }^{28}$ is a physical manifestation of the fluid, multifaceted nature of collective memory. National narratives are subject to change. Perhaps, in the future, those in power in New Zealand will decide that Captain Cook should no longer be venerated, and that statues of him should be removed. Indeed, the removal of monuments occurs relatively frequently. Turkish President Recep Erdogan has recently removed monuments dedicated to the secularist founder of modern Turkey, Mustafa Kemal Ataturk. ${ }^{29}$ This is part of a broader attempt by Erdogan to "erase Ataturk's memory

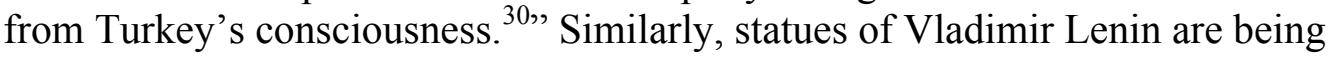
systematically torn down across Ukraine. There, the government seeks to eliminate Soviet symbolism from the mythscape and establish a uniform national narrative. Astonishingly, nearly 1000 statues of the Soviet leader have been removed since $2013 .^{31}$

\footnotetext{
${ }^{26}$ Ibid.

${ }^{27}$ Eduard Dolinsky, "What Ukraine's Jews Fear”, New York Times, 11 April 2017.

${ }^{28}$ No specified author, "Two charged with Dewar statue attack", BBC, 31 May 2002.

${ }^{29}$ No specified author, "Ataturk statue in Turkey's Rize moved to different location amid controversy", Daily News, 23 December 2016.

${ }^{30}$ Michael Rubin, “Will Erdogan airbrush Ataturk from Turkish life?”, Newsweek, 19 August 2016.

${ }^{31}$ Alex Matthews, "Ukraine destroys its largest remaining monument to Vladimir Lenin by tearing down giant statue of Soviet leader", Daily Mail, 19 March 2016.
} 


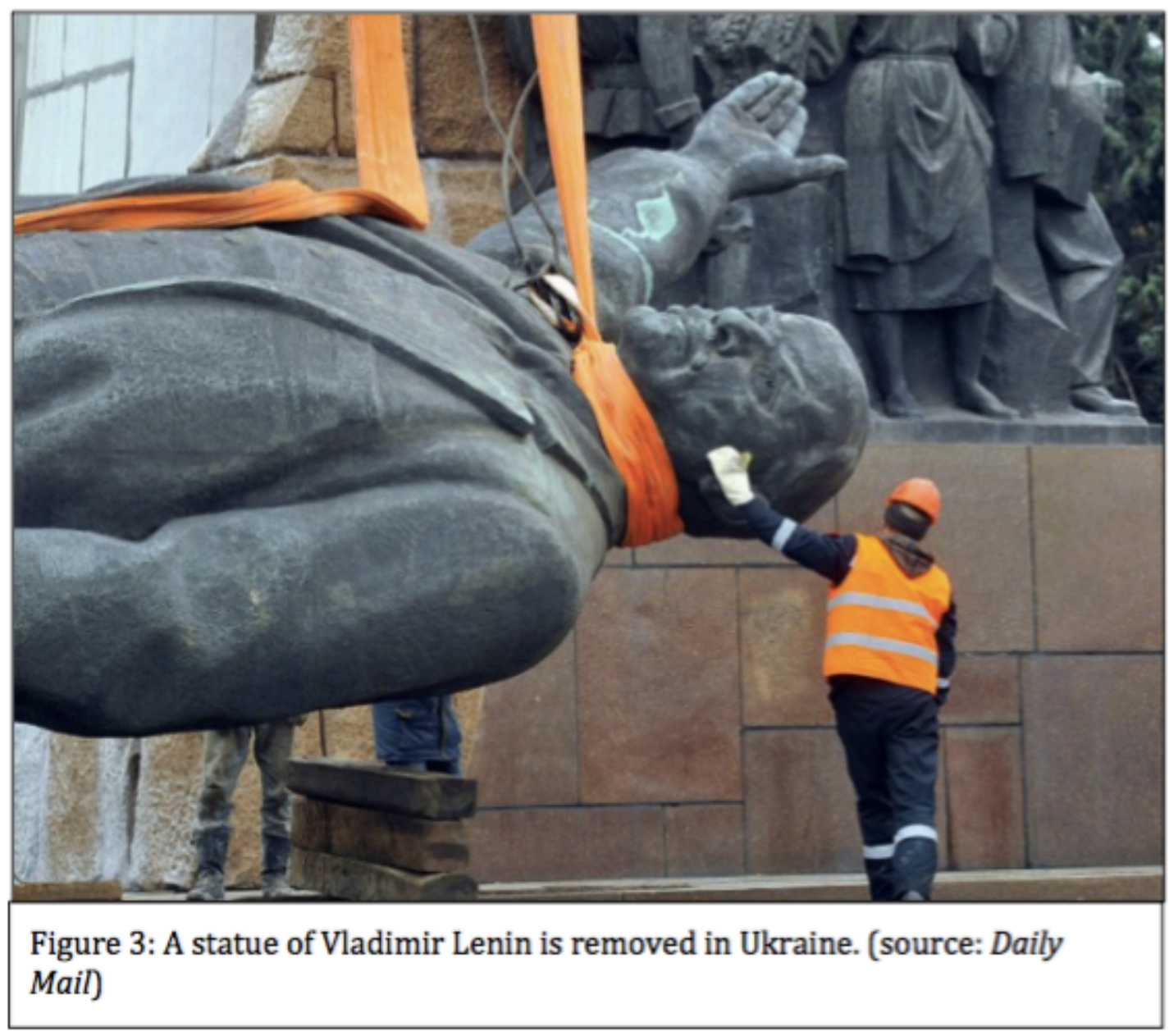

However, such attempts to create a homogenous, one-dimensional narrative of a nation's history are doomed to failure. In eastern Ukraine, crowds of civilians have turned out to defend statues of Lenin, and in some cases have prevented their demolition. ${ }^{32}$ In Adelaide, the South Australian National War Memorial will continue to induce national pride "not at all" for a noteworthy percentage of commuters. In Azerbaijan, many students will eventually be exposed to foreign perspectives regarding the history of their nation's conflict with Armenia. And in New Zealand, some will continue to demand that Captain Cook be removed from his pedestal. Despite how entrenched a given narrative appears, it inevitably co-exists with alternative narratives. And, despite how deeply these alternative narratives may be pushed underground, they always remain capable of bursting to the surface. Clearly, in no society does there actually exist a unitary collective memory.

\section{Conclusion}

There are many factors underpinning the importance of the role played by public monuments in memory wars. Namely, the importance of monuments owes to their capacity to shape collective memory both overtly and banally, their ability to embody

32 No specified author, "Crowd defends Lenin statue in eastern Ukraine city", $B B C, 23$ February 2017. 
simplified stories of the past, and their power to serve as vehicles for the expression of dissenting narrative strands. The prevalence of such dissent teaches us that, despite their best efforts, governments can never acquire absolute control over the mythscape, and thus cannot shape a truly homogenous collective memory amongst their people.

According to Homi Bhabha, nations themselves exist as nothing more than narratives of the past. In effect, this means that they exist only in collective memory. One is thus compelled to ask: if collective memory is splintered, does nation truly exist? The following comment is of interest. While conducting my survey, one man informed me that he was unable to respond to the questions that were being asked of him. He stated that, despite holding an Australian passport, "I do not know what "to be Australian" means." 


\section{Bibliography}

Akhundov, Sabir. "Azerbaijanism.” Open Democracy.

$<$ https://www.opendemocracy.net/od-russia/sabir-akhundov/azerbaijanism> (27 April 2017).

Alter, Peter. Nationalism. London: E. Arnold, 1994.

Basi, Kevin. "What we can learn from war memorials." Allied News. $<$ http://www.alliednews.com/opinion/columns/what-we-can-learn-fromwar-memorials/article_1ed8b5a2-8478-58cb-a1 df-01e6427ea595.html > (4 June 2017).

Bell, Duncan, "Mythscapes: Memory, Mythology and National Identity." British Journal of Sociology 54:1 (2003), 63-81.

Bhabha, Homi K. Nation and Narration. London; New York: Routledge, 1990.

Billig, Michael. Banal Nationalism. London: Thousand Oaks, 1995.

Blacklston, Hannah. "Where and how to commemorate ANZAC Day in your capital city." Nine.com.au.

$<$ http://elsewhere.nine.com.au/2017/04/19/14/38/where-and-how-tocommemorate-anzac-day-in-your-capital-city> (26 May 2017).

Chabun, Will. "Poignant commemoration of Holodomor tragedy in Regina." Regina Leader Post. <http://leaderpost.com/news/local-news/poignantcommemoration-of- ukrainian-holocaust> (24 May 2017).

Dolinsky, Eduard. "What Ukraine's Jews Fear." New York Times. $<$ https://www.nytimes.com/2017/04/11/opinion/what-ukraines-jewsfear.html?_r=0> (24 May 2017).

Halbwachs, Maurice. On Collective Memory. Chicago: University of Chicago Press, 1992.

Holbrook Carolyn. "How ANZAC Day came to occupy a sacred place in Australians' hearts." SBS $<$ http://www.sbs.com.au/topics/life/culture/article/2017/04/25/how- anzacday-came-occupy-sacred-place-australians-hearts> (30 May 2017).

Kramer, Lloyd, "Historical Narratives and the Meaning of Nationalism." Journal of the History of Ideas 58:3 (1997), 525-545.

Marples, David. Heroes and Villains: Creating National History in Contemporary Ukraine. Budapest: Central European University Press, 2007. 
Matthews, Alex. "Ukraine destroys its largest remaining monument to Vladimir Lenin by tearing down giant statue of Soviet leader." Daily Mail. $<$ http://www.dailymail.co.uk/news/article-3498967/Ukraine-destroyslargest- remaining-monument-Vladimir-Lenin-tearing-giant-statue-Sovietleader.html> (27 May 2017).

No specified author. "Leicester and New Delhi war memorials link ceremonies." $B B C .<\mathrm{http}: / / \mathrm{www}$. bbc.com/news/uk-england-leicestershire-40045122> (26 May 2017).

No specified author. "Queen lays wreath at Tomb of Unknown Soldier in Paris." $B B C$. <http://www.bbc.com/news/uk-27709345> (25 May 2017).

No specified author. "Two charged with Dewar statue attack." $B B C$. $<$ http://news.bbc.co.uk/2/hi/uk_news/scotland/2018129.stm> (27 May 2017).

No specified author. "Crowd defends Lenin statue in eastern Ukraine city." $B B C$. $<$ http:/www.bbc.com/news/av/world-europe-26313792/crowd-defendslenin- statue-in-eastern-ukraine-city> (26 May 2017).

No specified author. "Ataturk statue in Turkey's Rize moved to different location amid controversy." Daily News.

$<$ http://www.hurriyetdailynews.com/ataturk-statue-in- turkeys-rizemoved-to-different-location-amid-controversy.aspx ?PageID=238\&NID=107664\&NewsCatID=341> (26 May 2017).

No specified author. "Our students visited Guba genocide cemetery." Azerbaijan Republic Gabana Region Executive Power News. <http://www.qebeleih.gov.az/en/news/498.html> (30 April 2017).

Nora, Pierre, "Between memory and history: Les lieux de mémoire." Representations 26 (1989), 7-24.

Portnov, Andrii. "Bandera mythologies and their traps for Ukraine." Open Democracy. $<$ https://www.opendemocracy.net/od-russia/andriiportnov/bandera-mythologies- and-their-traps-for-ukraine> (26 May 2017).

Roy, Eleanor. "Captain Cook statues defaced in NZ amid calls for Maori chiefs to take his place." The Guardian.

$<$ https:/www.theguardian.com/world/2016/jul/31/captain- cook-statuesdefaced-in-nz-amid-calls-for-maori-chiefs-to-take-his-place> (27 May 2017).

Rubin, Michael. "Will Erdogan airbrush Ataturk from Turkish life?” Newsweek. $<$ http://www.newsweek.com/will-erdogan-airbrush-ataturk-turkish-life490823> (26 May 2017). 
Singman, Brooke. "President Trump gives Memorial Day Address at Arlington National Cemetery." Fox News.

$<$ http://www.foxnews.com/politics/2017/05/29/president-trump-givesmemorial-day-address-at-arlington-national-cemetery.html $>$ (29 May, 2017). 